\title{
Pengembangan Model Konseling untuk Penyalahgunaan Internet pada Remaja
}

\author{
Ervi Johan Lo, ${ }^{1}$ Go Heeng, ${ }^{2}$ David Martinus Gulo ${ }^{3}$ \\ Prodi Teologi, STT Real Batam \\ Prodi Teologi, STT Real Batam \\ Prodi Teologi, STT Real Batam \\ ervijohan@ymail.com
}

\begin{abstract}
The development of technology that is very rapid at this time, especially the internet can have a positive and negative impact on the lives of teenagers. In dealing with the abuse of the internet in adolescents, of course, it cannot be merely informed or advised. But it is necessary to develop appropriate counseling models in dealing with internet abuse in adolescents. The development of good, correct and effective counseling models will be able to prevent teenagers from abusing the internet or helping teenagers who have abused the internet so that they can utilize the internet properly and effectively. Therefore, the author introduces the development of a model of counseling in dealing with internet abuse in adolescents. This fatherly counseling model starts from loving counselors, accepting the counselee as he is so that the relationship between counselor and counselee is like a father to a child. Counselors do not judge counselees but forgive when counselees make mistakes, educate with values that are centered on Christ, and set an example to the counselee or adolescent who is served.
\end{abstract}

Keywords:Counseling, Internet, teenagers

\begin{abstract}
Abstrak
Perkembangan teknologi yang sangat pesat saat ini khususnya internet dapat memberikan dampak positif dan negatif dalam kehidupan para remaja. Dalam menghadapi penyalahgunaan internet pada remaja, tentunya tidak dapat hanya sekedar diberitahu atau dinasehati saja. Namun perlu pengembangan model konseling yang tepat dalam menghadapi penyalahgunaan internet pada remaja. Pengembangan model konseling yang baik, benar dan efektif akan dapat mencegah para remaja dalam penyalahgunaan internet ataupun menolong para remaja yang telah melakukan penyalahgunaan internet sehingga dapat mendayagunakan internet dengan benar dan efektif. Oleh karena itu penulis memperkenalkan pengembangan model konseling pembapaan dalam menghadapi penyalahgunaan internet pada remaja. Model konseling pembapaan ini dimulai dari konselor mengasihi, menerima konseli apa adanya sehingga tercipta hubungan antara konselor dan konseli seperti seorang bapa kepada anak. Konselor tidak menghakimi konseli namun mengampuni saat konseli melakukan kesalahan, mendidik dengan nilai-nilai yang berpusat pada Kristus, serta memberi teladan kepada konseli atau remaja yang dilayani.

Kata kunci:Konseling, Internet, remaja
\end{abstract}

\section{PENDAHULUAN}

Keberadaan internet sebagai penyedia informasi yang lengkap dan sangat cepat yang tersedia saat ini sangat memberikan kemudahan bagi setiap kalangan dalam masyarakat dalam melakukan aktivitas sehari-hari terutama dalam menjalankan tugas yang diemban seseorang. 
Dengan keberadaan internet, setiap orang dapat memperoleh informasi yang dibutuhkannya dengan sangat cepat dengan biaya yang relatif murah. Selain sebagai penyedia informasi, internet juga berfungsi sebagai sarana telekomunikasi sehingga memungkinkan penggunanya untuk dapat saling berkomunikasi dari jarak yang relatif jauh dan bahkan lintas antar negara dengan efektifitas waktu yang cepat dan biaya yang sangat murah.

Dewasa ini, istilah internet sudah bukan merupakan barang baru dalam kalangan masyarakat, bahkan sebagian besar anak-anak jaman sekarang sudah mengenal yang namanya internet bahkan sudah menggunakan fasilitas tersebut dalam kehidupan seharihari.

Semakin canggihnya perkembangan teknologi saat ini, menggunakan internet bukanlah hal yang sulit karena hampir semua handphone pada saat ini sudah berbasis android yang memiliki fasilitas lengkap termasuk akses untuk menelusuri dunia internet.

Internet merupakan topik yang agak rumit dibahas pada saat membahas tentang internet dikalangan remaja. Sebagian besar para remaja setuju bahwa internet benar-benar bermanfaat bagi mereka. Tanpa internet, hidup mereka menjadi hampa, tidak bergairah. Hampir semua kalangan masyarakat menikmati internet bahkan sebagian menyatakan bahwa peran internet sangat penting dalam kehidupan sehari-hari.

Internet telah banyak mempermudah kehidupan masyarakat dalam banyak hal tetapi disisi lain internet juga memiliki dampak negatif bagi penggunanya. Dengan banyaknya informasi yang tersedia di internet dan dapat diperoleh dengan bebas, sebagian juga penyalahgunaan informasi yang ada. Remaja saat ini mulai kehilangan kemampuan mereka untuk bersosialisasi dan berkomunikasi dengan orang lain karena mereka seringkali bersosialisasi dan berkomunikasi melalui internet.

Dengan hadirnya teknologi yang bernama internet telah menjadi seperti euforia tersendiri bagi pengguna teknologi di dunia. Tapi seperti halnya teknologi yang lain, internet juga memiliki 2 sisi yaitu sisi positif dan sisi negatif. Untuk mendapatkan sisi yang positif maka dibutuhkan karakter yang baik atau sikap yang bijak dalam menggunakan internet sebagai media teknologi yang dapat digunakan dalam hal yang positf juga dan juga sebaliknya jika penggunaan internet dilakukan untuk hal hal yang negatif maka internet akan menjadi momok yang sangat menakutkan bagi masyarakat dunia. ${ }^{1}$

Salah satu bagian dari masyarakat yang paling sering menggunakan internet adalah remaja. Remaja dapat memperoleh berbagai ilmu untuk kepentingan sekolahnya. Namun sangat disayangkan, seringkali penggunaan internet akhir-akhir ini malah sering disalahgunakan oleh para remaja.

Begitu juga di dalam kalangan remaja saat ini. Internet sudah menjadi sebuah kebutuhan pokok yang harus dimiliki dimana internet merupakan sarana untk memperoleh

\footnotetext{
${ }^{1}$ Surji, “Pengaruh Internet Terhadap Kehidupan Remaja Di Kota Padangsidimpuan Surji Universitas Graha Nusantara Padangsidimpuan," Indonesian Journal on Networking and Security - 4, no. 4 (2015): 1-8.
} 
informasi dengan cepat dan juga tersedia buku-buku online yang bisa didownload atau diunduh dengan mudah dan murah, membuat para remaja lebih leluasa untuk memperoleh pengetahuan tanpa harus bersusah payah untuk mencari buku atau referensi yang tepat. Namun hal ini tidak berarti buku referensi sudah tidak diperlukan lagi melainkan internet bisa digunakan sebagai referensi tambahan pada saat ada hal yang tidak dimengerti.

Dengan berbagai kemudahan yang ditawarkan melalui internet, menjadikan internet banyak dimanfaatkan oleh masyarakat tanpa terkecuali para remaja saat ini, yang memanfaatkan kecanggihan internet sebagai media pencari materi dan informasi pada saat mereka belajar dan mengerjakan tugas sehingga internet dapat dikatakan sangat membantu para remaja dalam mengerjakan tugas dari sekolah maupun untuk meningkatkan ilmu pengetahuan dan memperluas wawasan.

Anak merupakan salah satu lapisan masyarakat yang merupakan bagian dari generasi muda sebagai penerus cita-cita perjuangan bangsa dan bersumber daya manusia yang memiliki peran strategis dan mempunyai ciri dan sifat yang khusus, serta memerlukan pembinaan dan perlindungan dari orang tua maupun guru daiam rangka menjamin pertumbuhan dan perkembangan fisik, mental dan, sosial serta perlindungan dari segala kemungkinan yang akan membahayakan mereka. ${ }^{2}$

Internet banyak digunakan dalam kalangan remaja selain untuk mempermudah mereka mengakses berbagai macam informasi yang diperlukan dengan cepat dan murah, internet dapat digunakan sebagai sarana untuk menambah teman melalui situs sosial yang ada didalam internet tersebut seperti facebook dan instragram.

Kemajuan teknologi yang sangat pesat saat ini tidak dapat dihindari oleh siapapun juga. Penggunaan teknologi dengan tepat akan dapat sangat mempermudah kehidupan manusia, namun disamping itu juga dapat memberikan dampak buruk dalam kehidupan ini bila penggunaannya dengan cara yang tidak tepat.

Pesatnya perkembangan teknologi memberikan dampak positif saat ini, seperti mempercepat arus informasi, mempermudah akses terhadap informasi terbaru, menjadi media hiburan, mempermudah komunikasi dengan individu lainnya yang jauh, mempermudah bisnis online, dan sebagainya. Namun pesatnya kemajuan teknologi ini juga dapat memberikan dampak negatif seperti: menjadikan seseorang menjadi individualis (Individu menjadi malas untuk bersosialisasi secara fisik), meningkatnya penipuan dan juga kejahatan cyber, konten negatif yang berkembang pesat (pornografi, berita hoax dan sebagainya), fitnah dan juga pencemaran nama baik secara luas, menjauhkan yang dekat, mengabaikan tugas dan juga pekerjaan, kecanduan internet/game, membuang-buang waktu untuk hal yang tidak berguna (tidak bermanfaat), menurunnya prestasi belajar dan juga kemampuan bekerja seseorang menjadi tidak maksimal, dan sebagainya.

\footnotetext{
${ }^{2}$ Marcelino Sumolang, "Peranan Internet Terhadap Generasi Muda Di Desa Tounelet Kecamatan Langowan Barat," jurnal TEKNOIF 3, no. 2 (2013): 19.
} 
Internet memberikan banyak dampak positif dengan informasi-informasi di dalamnya, tetapi di pihak lain internet juga menimbulkan dampak negatif karena informasi yang terdapat dalam internet sulit untuk dibatasi, berbagai macam informasi dalam berbagai bentuk dan tujuan bercampur menjadi satu di mana untuk mengaksesnya hanya perlu memasukkan beberapa kata kunci saja. ${ }^{3}$

Dampak negatif dari penyalahgunaan internet ini juga terlihat pada gangguan kesehatan, seperti: gangguan kesehatan seperti mata menjadi cepat lelah, kualitas penglihatan memudar, dan ketegangan pada mata, gangguan mental dan pemborosan. Sakit leher karena terlalu lama menatap layar gadget. Insomia /tidak dapat tidur karena waktu tidur yang tidak berarturan yang diakibatkan oleh penyalahgunaan internet. Disamping itu juga dapat mengakibatkan terjadinya kecelakaan karena menurunnya daya konsentrasi akibat membagi perhatian dengan gadget.

Sutantro dalam Jurnal Remaja dan Internet mengungkapkan survei global yang diadakan oleh Latitude News pada tahun 2012, Indonesia merupakan negara dengan kasus bullying tertinggi kedua di dunia setelah Jepang. Kasus bullying di Indonesia ternyata mengalahkan kasus bullying di Amerika Serikat yang menempati posisi ketiga. Ironisnya, kasus bullying di Indonesia lebih banyak dilakukan di media sosial. ${ }^{4}$

Gadget merupakan media elektronik yang berbentuk handphone, smartphone, laptop dan tablet. Gadget merupakan alat untuk menjalankan semua media sosial yang ada, bahkan di kalangan para remaja banyak yang sudah menggunakan gadget yang terhubung dengan jaringan internet untuk bermain games, mendapatkan informasi dan menjalin komunikasi.

Penggunaan internet dan gadget dapat memberikan dampak yang positif maupun dampak yang negatif bagi para remaja. Dampak positifnya adalah memudahkan remaja untuk berkomunikasi dengan banyak orang tanpa memerlukan biaya yang besar. Melalui jejaring sosial, seorang remaja dapat berkomunikasi dengan orang lain yang berasal dari negara lain. Selain itu, dengan adanya kemajuan teknologi, seorang remaja bisa menemukan permainan yang kreatif. Tetapi tidak semua penggunaan gadget berdampak positif bagi kehidupan para remaja. Penggunaan gadget yang berlebihan bisa menimbulkan adanya penurunan dalam hal berkomunikasi dan bersosialisasi. Remaja sepertinya tidak peduli dengan sesama serta tidak memahami etika bersosialisasi dengan lingkungan sekitarnya.

Penyalahgunaan internet dalam dunia remaja seringkali mengakibatkan orang tua, guru/pendidik mengalami kebingungan. Karena itu perlu dilakukan usaha-usaha dalam mencegah sehingga tidak terjadi penyalahgunaan internet pada dunia remaja ataupun untuk

\footnotetext{
3 "POLA PENGGUNAAN INTERNET OLEH KALANGAN REMAJA DI KABUPATEN SEMARANG Ester Krisnawati," Cakrawala Jurnal Penelitian Sosial 4, no. 2 (2015): 319-350.

${ }^{4}$ Siti Nurina Hakim, Aliffatullah Alyu Raj, and Dara Febrian Chita Prastiwi, "Remaja Dan Internet," in Prosiding SEMNAS Penguatan Individu Di Era Revolusi Informasi, vol. 2, 2016, 311-319, https://publikasiilmiah.ums.ac.id/bitstream/handle/11617/9290/Siti Nurina Hakim.pdf?sequence=1\&isAllowed=y.
} 
membantu remaja-remaja yang terlibat penyalahgunaan internet sehingga dapat menggunakannya dengan tepat.

Bila diibaratkan, internet seperti sebuah pisau yang tajam yang dapat melukai orang lain atau pemakainya, namun dapat juga bermanfaat dan sangat membantu bagi pemakainya. Karena pisau dapat membahayakan, lalu apakah sebaiknya setiap orang dilarang menggunakan pisau? Oleh karena itu, dalam menghadapi perkembangan teknologi, khususnya gadget dan internet, maka yang dilakukan bukanlah melarang para remaja menggunakan internet/gadget, melainkan mengajarkan para remaja cara menggunakan internet/gadget dengan bijak, sehingga internet/gadget tersebut dapat digunakan dengan efektif.

This paper describes the problems that occur and can be scientifically proven or can be investigated by methodological, hermeneutic, exegesis approaches. In this introduction, a thesis will be explained which will be described or examined to answer issues, and issues are surrounding theology, Christian and pastoral education which can be interpreted in an argumentative and quantitative, qualitative and other measurable data analysis.

\section{METODE}

Metode penelitian yang digunakan adalah metode kualitatif studi literature dengan melihat Alkitab sebagai sumber utama dan juga buku buku, jurnal-jurnal penunjang serta hasi hasil penelitian lainnya yang telah dipublikasikan, membahas tentang model konseling terhadap remaja yang menyalahgunakan Internet.

\section{HASIL DAN PEMBAHASAN}

\section{Penyalahgunaan internet pada remaja}

Di Indonesia, pengguna internet terbesar adalah remaja dengan rentang usia 15-24 tahun dengan kisaran rentang prosentase $26,7 \%$ - 30\%. Kemudahan akses internet ini tidak selamanya berdampak positif. Hampir 80\% remaja berusia 10-19 tahun yang tersebar di 11 provinsi di Indonesia kecanduan internet, dan sebagian besar remaja menggunakan internet untuk hal-hal yang tidak semestinya. 24\% mengaku menggunakan internet untuk berinteraksi dengan orang yang tidak dikenal, $14 \%$ mengakses konten pornografi, dan sisanya untuk game online dan kepentingan lainnya. ${ }^{5}$

Hasil uji hipotesis penelitian yang menggunakan teknik analisis regresi sederhana dengan bantuan komputer melalui program SPSS (Statistical Package for Social Science) for Windows Releaseversi 21.0 diperoleh hasil $\mathrm{rxy}=-0,369$ pada $\mathrm{p}=$ $0,000$ ( $\mathrm{p}<0,005)$. Koefisien korelasi tersebut mengindikasikan adanya hubungan antara variabel kontrol diri dengan kecenderungan kecanduan media sosial. Tingkat

\footnotetext{
${ }^{5}$ Siti Nurina Hakim, Aliffatullah Alyu Raj, and Hasil Pembahasan, “Dampak Kecanduan Internet (Internet Addiction) Pada Remaja," in Peran Psikologi Perkembangan Dalam Penumbuhan Humanitas Pada Era Digital, 2017, 280-284.
} 
signifikan sebesar $\mathrm{p}<0,005$ menunjukkan bahwa terdapat hubungan yang signifikan antara kontrol diri dengan kecenderungan kecanduan media sosial. Nilai negatif pada koefisien korelasi menunjukkan bahwa semakin rendah kemampuan kontrol diri yang dimiliki remaja, maka kecenderungan kecanduan media sosial akan semakin tinggi. Begitu sebaliknya, semakin tinggi kemampuan kontrol diri yang dimiliki remaja, maka kecenderungan kecanduan media sosial akan semakin rendah. ${ }^{6}$

Hal yang menarik ketika berbicara penyalahgunaan internet pada remaja adalah banyaknya para remaja yang telah menyalahgunakan internet, namun tidak menyadari bahwa mereka telah menyalahgunakannya. Seperti : membobol password wifi sekolahan, meng"crack" game ataupun program yang ada, main game berjam-jam sehingga mengabaikan tugas sekolah ataupun aktifitas lainnya, membuat video-video untuk mem"buly" satu sama lain, dan sebagainya. Ada beberapa penyebab penyalahgunaan internet pada remaja seperti:

- Kurangnya pendidikan menggunakan internet / teknologi dengan benar, merupakan salah satu penyebab remaja terus melakukan penyalahgunaan. Oleh karena itu perlu dilakukan pendidikan dan pendampingan yang benar yang dilakukan oleh orang tua dan guru / para pendidik serta lingkungan yang ada di sekitar dunia remaja.

- Adanya kesempatan yang diberikan oleh orang tua untuk seorang remaja menyalahgunakan internet / teknologi. Seperti: membiarkan anak berjam-jam terus bermain gadget ataupun HP, sehingga anak kurang bersosialisasi.

- Sikap cuek / tidak mau tahu yang dimiliki orang tua terhadap kemajuan teknologi. Orang tua yang gaptek (gagap teknologi) disadari atau tidak akan menciptakan jarak antara orang tua dan anak.

- Problem emosional yang dialami remaja seperti: kurang perhatian, kurang kasih sayang, kurang dihargai, kekecewaan dan sebagainya. Hal ini menyebabkan para remaja mengisi kekosongan yang ada dalam hatinya dengan melampiaskannya melalui internet. Ada yang melampiaskannya dengan bermain game, ada yang membuly orang lain sebagai ungkapan kekecewaannya, ada yang menonton pornografi, ada yang mencurahkan emosionalnya kedalam status facebook, instagram dan sebagainya.

Untuk mengatasi ini semua ada banyak usaha yang dilakukan dalam mengurangi penyalahgunaan internet ini, seperti: memarahi ataupun melarang remaja yang bermain internet. Hal ini tentunya tidak menyelesaikan masalah, malah menciptakan jarak antara orang tua dan remaja. Mungkin di depan orang tua remaja tersebut tidak bermain internet secara berlebihan, namun begitu ada kesempatan untuk bermain internet maka akan membuat remaja tersebut semakin "menggila" dalam bermain internet.

\footnotetext{
${ }^{6}$ Resti Fauzul Muna and Tri Puji Astuti, "Hubungan Antara Kontrol Diri Dengan Kecenderungan Kecanduan Media Sosial Pada Remaja Akhir," Empati: Jurnal Karya Ilmiah S1 Undip 3, no. 4 (2014): 481-491.
} 


\section{Model konseling dalam menghadapi penyalahgunaan internet pada remaja}

Konseling yang dilakukan dalam menghadapi penyalahgunaan internet pada remaja memiliki dua sasaran, yakni untuk pencegahan dan untuk membantu remaja-remaja yang sudah terlibat dalam penyalahgunaan internet (membuly, pornografi, hacker, dan sebagainya).

Dalam melakukan konseling, tentunya ada beberapa hal yang perlu diperhatikan, yaitu: siapa yang mengkonseling, apa yang disampaikan, bagaimana respon konseli / remaja terhadap konselornya, seberapa sering konseling dilakukan, dan sebagainya.

Kebanyakan konseling dan nasihat yang diterima oleh orang-orang adalah menyuruh mereka melakukan sesuatu. Itulah sebabnya sebagian besar program pemulihan Kristen tidak melihat banyak kemerdekaan di dalam Kristus. ${ }^{7}$ Ketika seorang remaja yang dalam masalah, disuruh melakukan sesuatu, maka akan muncul kesulitan yang dihadapi oleh remaja tersebut. Dalam buku Membangun pribadi unggul, juga dikatakan: "Kita sering ingin mengubah orang lain agar bersikap dan berperilaku seperti yang kita kehendaki,.... Kecenderungan kita adalah menerapkan ukuran, patokan, norma, syarat dan orang lain harus menyesuaikan diri atau tunduk". ${ }^{8}$ Sebenarnya konselor yang berpusat pada tuntutan untuk seseorang mengalami perubahan, sesungguhnya sedang menambahkan beban kepada konseli. Seperti yang dilakukan oleh banyak orang tua adalah memarahi/melarang remaja untuk bermain internet, maka sebagian remaja akan menurut dengan terpaksa (karena takut dimarahi), ataupun sebagian lagi menjadi memberontak kepada orang tuanya. Jadi bagaimanakah sikap yang harus dilakukan orang tua?

Model konseling yang efektif untuk mencegah ataupun membantu remaja yang terlibat dalam penyalahgunaan internet adalah model konseling pembapaan. Seorang konselor dalam model konseling pembapaan ini bukan sekedar menjadi narasumber bagi remaja, namun memiliki hubungan yang baik dengan konseli / remaja sehingga remaja tersebut respek / mau mendengarkan dan mentaati nasehat yang diberikan oleh konsleor. Konselor dalam model konseling pembapaan ini mengasihi, menerima, dan mengampuni, konseli / remaja sama seperti Kristus telah mengasihi, menerima dan mengampuni (Yoh 13:34; Roma 15:7; Kol 3:13). Jadi konselor bukan menghakimi konseli, melainkan menyelamatkannya (Yoh 3:17).Teladan yang diberikan oleh konselor model pembapaan ini juga menjadi hal yang sangat penting bagi remaja sehingga remaja dapat mengikuti teladan hidup konselor. Teladan hidup ini dapat berupa teladan dalam bersosial, menggunakan internet dengan bijaksana (tidak kecanduan game), dan sebagainya.

Konselor dalam model konseling pembapaan ini juga mendidik konseli dengan nilai-nilai yang berpusat pada Kristus sehingga remaja dapat membedakan informasi yang diterimanya. Kewajiban seorang bapa dalam pembapaan adalah membawa para remaja

\footnotetext{
${ }^{7}$ Steve McVey and Mike Quarkes, Menolong Orang Lain Mengatasi Kecanduan (Jakarta: Tangan Pengharapan, 2012). 65

${ }^{8}$ B.S. Sidjabat, Membangun Pribadi Yang Unggul (Yogyakarta: ANDI, 2011).208
} 
datang kepada Tuhan, menceritakan perbuatan-perbuatan Tuhan yang besar (1Pet 2:9). Kehadiran seorang konselor / bapa dalam kehidupan para remaja menjadi sangat penting dalam model konseling pembapaan ini. Konselor akan mengisi waktu-waktu bersama konseli dan memberikan teladan cara menggunakan internet dengan benar.

Menanamkan nilai-nilai (merubah mindset yang salah) dengan cara menanamkan kebenaran Firman Kristus di dalam diri anak remaja saat ini (2 Tim 3:16; Ul 6"6-7; 2Tim1:5-6). Saat remaja memiliki nilai-nilai/prinsip yang benar, maka ia akan dapat membedakan informasi yang relevan dan tidak relevan, berguna atau tidak berguna, tepat waktu atau tidak tepat waktu, benar atau hoax, sehingga remaja tidak mudah terseret kepada informasi / nilai-nilai yang salah. Proses penanaman nilai-nilai ini akan jauh lebih maksimal bila dilakukan oleh seorang bapa dan dilakukan secara berulang-ulang (U1 6:7). Keluarga menjadi informasi awal dan utama bagi seorang remaja.

Keluarga harus bisa mengambil berbagai keuntungan dan manfaat dari kemajuan teknologi (khususnya dalam hal ini adalah internet) dan meminimalkan efek negatif yang mempengaruhinya. Seorang Bapa tidak dapat menarik anak remajanya untuk menjauhi perkembangan teknologi tetapi harus mendampingi anak remaja dan membantu memilah setiap informasi yang diperoleh serta membimbing remaja untuk mengikuti perkembangan yang ada.

Masalah utama sesungguhnya bukanlah di internetnya, melainkan di problem emosional anak seperti merasa kesepian, kurang perhatian (merasa teman medsos lebih memperhatikannya) sehingga mengejar like, dan sebagainya. Oleh karena itu pengembangan model konseling pembapaan ini menjadi jawaban dalam mencegah remaja menyalahgunakan internet dan membantu para remaja yang menyalahgunakan internet sehingga dapat menggunakannya dengan benar dan tepat sasaran.

Dalam Ulangan 6:7 dikatakan demikian : "haruslah engkau mengajarkannya berulang-ulang kepada anak-anakmu dan membicarakannya apabila engkau duduk di rumahmu,...”. Didalam setiap kesempatan yang ada, perlu mengingatkan remaja mengenai Firman Tuhan terutama melalui mezbah keluarga dan ibadah di gereja. Jika remaja sudah mengerti nilai-nilai kebenaran Firman Tuhan maka remaja pasti bisa membedakan mana yang benar dan mana yang tidak benar sehingga remaja dapat mengambil keputusan sesuai dengan nilai-nilai Firman Tuhan yang sudah dimilikinya dan dapat menghadapi dampakdampak yang kurang baik dari internet.

\section{KESIMPULAN}


Perkembangan teknologi internet tidak dapat dihindari dan tidak dapat dibendung lagi. Internet tidak terlepas dari pengaruh positif dan negatif sehingga peran serta orang tua sangat besar pengaruhnya untuk meminimalisasi sisi negatif dari penggunaaan internet.

Oleh karena itu para orang tua tidak dapat lagi melarang para remaja dalam menggunakan internet. Namun para orang tua dapat menjalankan fungsi pembapaan dalam mencegah para remaja melakukan penyalahgunaan internet ataupun menolong para remaja yang telah melakukan penyalahgunaan internet. Komunikasi orang tua dan anak sangat diperlukan untuk meminimalkan sisi negatifnya.

Sebagai remaja juga harus bisa bersikap bijak dalam mengikuti arus perkembangan teknologi yang begitu cepat khususnya dalam bidang internet yang ada saat ini sehingga para remaja tidak terjebak dalam menggunaan internet yang berdampak negatif terhadap remaja itu sendiri.

Model konseling yang efektif untuk mencegah ataupun membantu remaja yang terlibat dalam penyalahgunaan internet adalah model konseling pembapaan. Seorang konselor dalam model konseling pembapaan ini membangun hubungan sama konseli dengan cara mengasihi, menerima, mengampuni, mendidik dengan nilai-nilai yang berpusat pada Kristus, serta memberi teladan kepada konseli / remaja yang dilayani.

Seorang bapa mampu untuk selalu menyediakan waktu yang berkualitas dengan remaja di rumah atau dimana saja dan menuntun remaja untuk dapat memilih nilai-nilai yang baik yang ditawarkan dari internet serta membimbing remaja untuk menjadi berkat dimanapun mereka berada.

Sebagai seorang remaja, juga harus dapat bijaksana dalam mengikuti arus perkembangan internet yang ada sekarang ini sehingga tidak terjebak dalam pergaulan yang kurang baik yang diperoleh dari penggunaan internet.

\section{KEPUSTAKAAN}

Hakim, Siti Nurina, Aliffatullah Alyu Raj, and Hasil Pembahasan. "Dampak Kecanduan Internet (Internet Addiction) Pada Remaja.” In Peran Psikologi Perkembangan Dalam Penumbuhan Humanitas Pada Era Digital, 280-284, 2017.

Hakim, Siti Nurina, Aliffatullah Alyu Raj, and Dara Febrian Chita Prastiwi. "Remaja Dan Internet." In Prosiding SEMNAS Penguatan Individu Di Era Revolusi Informasi, 2:311-319, 2016. https://publikasiilmiah.ums.ac.id/bitstream/handle/11617/9290/Siti Nurina Hakim.pdf?sequence $=1 \&$ isAllowed $=\mathrm{y}$.

McVey, Steve, and Mike Quarkes. Menolong Orang Lain Mengatasi Kecanduan. Jakarta: Tangan Pengharapan, 2012.

Muna, Resti Fauzul, and Tri Puji Astuti. "Hubungan Antara Kontrol Diri Dengan Kecenderungan Kecanduan Media Sosial Pada Remaja Akhir.” Empati: Jurnal Karya Ilmiah S1 Undip 3, no. 4 (2014): 481-491.

Sidjabat, B.S. Membangun Pribadi Yang Unggul. Yogyakarta: ANDI, 2011.

Sumolang, Marcelino. "Peranan Internet Terhadap Generasi Muda Di Desa Tounelet Kecamatan Langowan Barat.” jurnal TEKNOIF 3, no. 2 (2013): 19.

Surji. "Pengaruh Internet Terhadap Kehidupan Remaja Di Kota Padangsidimpuan Surji 
Universitas Graha Nusantara Padangsidimpuan.” Indonesian Journal on Networking and Security - 4, no. 4 (2015): 1-8.

"POLA PENGGUNAAN INTERNET OLEH KALANGAN REMAJA DI KABUPATEN SEMARANG Ester Krisnawati." Cakrawala Jurnal Penelitian Sosial 4, no. 2 (2015): 319-350. 